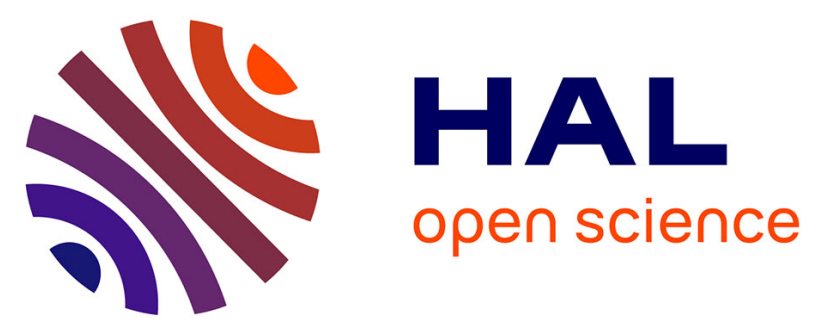

\title{
Short-term plant legacy alters the resistance and resilience of soil microbial communities exposed to heat disturbance in a Mediterranean calcareous soil
} Ana Beatriz de Oliveira, Amélie A. M. Cantarel, Marie Seiller, Alessandro Florio, Annette Berard, Philippe Hinsinger, Edith Le Cadre-Barthélemy

\section{To cite this version:}

Ana Beatriz de Oliveira, Amélie A. M. Cantarel, Marie Seiller, Alessandro Florio, Annette Berard, et al.. Short-term plant legacy alters the resistance and resilience of soil microbial communities exposed to heat disturbance in a Mediterranean calcareous soil. Ecological Indicators, 2020, 108, pp.105740. 10.1016/j.ecolind.2019.105740 . hal-02365828

\section{HAL Id: hal-02365828}

\section{https://institut-agro-rennes-angers.hal.science/hal-02365828}

Submitted on 21 Dec 2021

HAL is a multi-disciplinary open access archive for the deposit and dissemination of scientific research documents, whether they are published or not. The documents may come from teaching and research institutions in France or abroad, or from public or private research centers.
L'archive ouverte pluridisciplinaire HAL, est destinée au dépôt et à la diffusion de documents scientifiques de niveau recherche, publiés ou non, émanant des établissements d'enseignement et de recherche français ou étrangers, des laboratoires publics ou privés.

\section{(ㄷ)(1) $\$$}

Distributed under a Creative Commons Attribution - NonCommerciall 4.0 International 
1 Title: Short-term plant legacy alters the resistance and resilience of soil microbial 2 communities exposed to heat disturbance in a Mediterranean calcareous soil.

3 Ana Beatriz de Oliveira ${ }^{\mathrm{a}}$, Amélie A. M. Cantarel $^{\mathrm{b}}$, Marie Seiller ${ }^{\mathrm{a}}$, Alessandro Florio ${ }^{\mathrm{b}}$, Annette 4 Bérard $^{\mathrm{c}}$, Philippe Hinsinger ${ }^{\mathrm{d}}$, Edith Le Cadre ${ }^{\mathrm{a}, 1}$

aUMR SAS, AGROCAMPUS OUEST, INRA, bâtiment 13, 65 rue de Saint-Brieuc CS 84215,

6 35042, Rennes Cedex, France. E-mails: ana-beatriz.de-oliveira@inra.fr;

7 marie.seiller@agrocampus-ouest.fr

8 'baboratoire d'Ecologie Microbienne LEM, UMR INRA 1418, UMR CNRS 5557, INRA,

9 CNRS, Université Lyon1, Université de Lyon, bâtiment G. Mendel, 43 boulevard du 11

10 novembre 1918, F-69622 Villeurbanne Cedex, France. E-mails: amelie.cantarel@univ-

11 lyon1.fr; alessandro.florio@univ-lyon1.fr

${ }^{\text {c} U M R ~ E M M A H, ~ I N R A, ~} 228$ route de l'Aérodrome, Domaine Saint-Paul - Site Agroparc, CS 40509, 84914, Avignon Cedex 9, France. E-mail: annette.berard@inra.fr

14 dUMR Eco\&Sols, Univ Montpellier, INRA, CIRAD, IRD, Montpellier SupAgro, Bâtiment 12, 2 Place Viala, 34060, Montpellier Cedex 2, France. E-mail: philippe.hinsinger@inra.fr

${ }^{1}$ corresponding author : 84 215, 35042 Rennes cedex, France 
Plant legacy is a concept representing the effects exerted by plants on soil once they are no longer growing. We hypothesized that plant species and mixture (intercropping) would induce different short-term legacy effects impacting carbon and nitrogen-related soil microbial activities and resistance and resilience after a heat disturbance. A microcosm experiment was conducted using a calcareous Mediterranean soil conditioned by a complete vegetative cycle in a greenhouse with four planting modalities $(\mathrm{W}=$ monoculture of Wheat (Triticum aestivum L.); $\mathrm{L}=$ monoculture of white Lupin (Lupinus albus $\mathrm{L}$.); $\mathrm{WL}=$ both species intercropped; $\mathrm{U}=$ unplanted soil). Half of microcosms were incubated at $28^{\circ} \mathrm{C}(\mathrm{C}=$ control conditions $)$ whereas the remaining half were exposed at $48^{\circ} \mathrm{C}$ for 2 days $(\mathrm{S}=$ stress conditions), with an immediately return to control conditions. Microcosms were destructively sampled at 2, 7, 16 and 28 days (T2, T7, T16, T28) after the end of the heat disturbance and the following soil measurements were performed: Basal Respiration (BR), Substrate-Induced Respiration (SIR), Nitrification Enzyme Activity (NEA) and N mineral concentrations. Our results demonstrated that monocultures and intercropping promoted different legacy effects under control conditions especially for SIR. WL soils presented lower values of SIR than L and higher than W soils. For SIR, W and WL soils conferred greater resistance to the heat stress, whereas L and WL soils conferred higher resilience at T28. For NEA, no differences between soils were observed for resistance to heat stress, but at T16, soils having WL legacy were more resilient than L soils, but comparable to those having W legacy. Our results highlight that a short-term legacy effect is measurable but greatly differs between $\mathrm{C}$ - and N-related microbial activities. We estimated that intercropping had modified ability of soil microorganisms to face heat stress, suggesting that plant legacy effect has to be considered to mitigate extreme climatic events in Mediterranean soils. 
48 Keywords: climate change; soil respiration; nitrification; crop mixture; plant soil feedback, 49 heat stress. 
Substantial legacy effects on soil properties are induced by plants and can persist after the disappearance of those plants that were responsible for these effects (van Der Putten et al., 2013) . Plant legacy effects have been pointed out to influence carbon storage in soils (Lange et al., 2015), succession in plant communities (van der Putten et al., 2016) or plant invasions (Bailey and Schweitzer, 2016). Legacy effects of plants on soils are largely driven by shifts in soil microbial communities. Indeed, plant roots can directly alter soil microbial communities by releasing carbon compounds named rhizodeposits (Eisenhauer et al., 2017; Hunter et al., 2014; Kuzyakov and Blagodatskaya, 2015). Rhizodeposits include a wide range of organic compounds including specific root exudates that shape microbial communities in root vicinity, i.e. the rhizosphere microbiome (Dennis et al., 2010; Li et al., 2018). Furthermore, composition of rhizodeposits is known to be plant specific (Hunter et al., 2014; Li et al., 2018), which suggests that a single species will affect differently soil microbial communities compared to a plant mixture (Chen et al., 2019; Eisenhauer et al., 2017; Tang et al., 2014; Tang et al., 2016). Plants are also able to alter soil microbial communities indirectly by modifying the abiotic properties of the soil, i.e. $\mathrm{pH}$, nutrient availability, moisture or soil structure (Hinsinger et al., 2009). Several plant legacies were characterized in grasslands (Grman and Suding, 2010; Lange et al., 2015; Strecker et al., 2016; Zak et al., 2003), but debated in agroecosystems while recent publication pointed out its implication in shaping soil microbiome (Li et al., 2018). In agroecosystems, the frequency of perturbations due to annual practices and the low plant diversity barely support comparison to natural ecosystems. However, some agronomic practices such as intercropping are in rupture with conventional agriculture, as it consists to grow two or more species or genotypes in the same field during a significant period of their life cycle (Brooker et al., 2015). Intercropping is of great interest in many countries as a solution to replace synthetic inputs by ecological processes (Brooker et 
al., 2015; Doré et al., 2011; Malézieux et al., 2009). Long-term legacy effects of intercropping have been estimated by Cong et al. (2015), but within 1-year timespan authors are reluctant to expect a significant effect on soil communities. However, Pivato et al. (2017) estimated that after only 12 weeks of bi-species culture, $\mathrm{N}$ cycling-related microbial communities were strongly affected especially at low $\mathrm{N}$ level compared to each species in monoculture. Grman and Suding (2010) also estimated a short-term legacy effect pointing out the multiple drivers defining both plant legacy duration and intensity. Given the crucial role of soil microbial activities in ecosystem functioning, these plant legacy effects can contribute to agroecosystem stability in the context of climate change and particularly during extreme events. Several studies have been focused on resistance (capacity to withstand change) and resilience (capacity for recovering of function) of C-related soil microbial activities to environmental disturbances (Bérard et al., 2012; Bérard et al., 2011; Chaer et al., 2009; Guillot et al., 2019; Hamdi et al., 2011; Mooshammer et al., 2017; Orwin and Wardle, 2005). However, studies about stability of more specialized soil microbial communities like nitrifiers are scarce (Mooshammer et al., 2017; Thion and Prosser, 2014; Wertz et al., 2007). Yet there are reasons to argue that plants are able to shape soil related N-cycle communities (Zak et al., 2003). Our rationale is to consider that diverse plant species yield different legacies, ultimately contributing to alleviate effects of extreme climatic events as heat waves in agroecosystems. We hypothesized that intercropped species promote a (i) different legacy effect on soil microbial processes in comparison to single species, and accordingly (ii) influence the resistance and resilience of soils. We focused on nitrification and respiration microbial processes (potential nitrification, substrate-induced respiration and basal respiration) as key processes of the $\mathrm{N}$ and $\mathrm{C}$ cycles in environmental and plant productivity issues. To achieve this goal, we generated a novel plant legacy in a calcareous cambisol, through a greenhouse experiment conducted with a soil collected in a Mediterranean site near 
100 Montpellier, France. Soil was collected 3 months after a pea crop, sieved at 1-cm to be

101 homogenized and ridded of any coarse organic material, then air dried and stored at ambient temperature before use. In 2017, soil was mixed with perlite and conditioned by one complete

103 vegetative cycle of two crop species grown as single crops (monocultures), (i) white lupin

104 (Lupinus albus L.) and (ii) bread wheat (Triticum aestivum L.), as well as the mixture of both 105 species (intercrop). Finally, we calculated the resistance and resilience indices (sensu Orwin 106 and Wardle (2004)) after a heat disturbance.

\section{Material and methods}

\subsection{Soil origin and greenhouse experiment before heat stress experiment}

Soil originated from a plot of the INRA experimental station localized at Mauguio

111 (3 $3^{\circ} 9^{\prime} 6^{\prime \prime} \mathrm{E}, 43^{\circ} 37^{\prime} 13^{\prime \prime} \mathrm{N}, 12 \mathrm{~m}$ altitude) in French littoral Mediterranean region. The soil was a

112 calcareous cambisol with a clay loam texture according to USDA classification (clay $294 \mathrm{~g}$

$113 \mathrm{~kg}^{-1}$, fine silt $200 \mathrm{~g} \mathrm{~kg}^{-1}$, coarse silt $233 \mathrm{~g} \mathrm{~kg}^{-1}$, fine sand $156 \mathrm{~g} \mathrm{~kg}^{-1}$ and coarse sand $118 \mathrm{~g} \mathrm{~kg}^{-}$

$114^{1}$ ), which had developed on an alluvial calcareous parent material, typical of the South East 115 plains of Montpellier. The regional climate is typically Mediterranean with surface regularly 116 exposed to drying-rewetting cycles due to irregular rain events mainly concentrated in 117 Autumn and Spring. The annual average rainfall at this site during the growing season, from 118 September to June, over the last 20 years was $598 \mathrm{~mm}$. Recorded average soil temperatures at $11910 \mathrm{~cm}$ depth since 2012 demonstrated that plot had never experienced temperatures higher 120 than $38.4{ }^{\circ} \mathrm{C}$. During the four months before soil sampling, 3 cycles of drought were recorded 121 (i.e. 20 days with cumulative rainfall lower than $2 \mathrm{~mm}$, according to Tang et al. (2014)), while maximal air temperatures ranged from $22.8^{\circ} \mathrm{C}$ (in September) to $34.7^{\circ} \mathrm{C}$ (in August). The last

123 precipitation episode $(4.8 \mathrm{~mm})$ preceding soil sampling occurred 5 days earlier. Soil was 124 collected $(0-15 \mathrm{~cm}$ depth) 3 months after pea harvest, air dried and sieved at $1-\mathrm{cm}$ to 
125 homogenize and remove coarse organic material, then finally stored at ambient temperature before use to preserve inherent soil quality (Salomé et al., 2014).

A pot experiment was then conducted in a greenhouse (Centre Mondial de

128 l'Innovation - Roullier Group - Saint-Malo, France) from September to December 2017 with

129 the soil previously described. Before being conditioned in the pots $\left(4-\mathrm{dm}^{3}\right)$, the soil was re-

130 sieved with a 4-mm mesh to remove any organic material and mixed with perlite to allow

131 better conditions for plant root development. Pots were filled with substrate composed of $2 \mathrm{~kg}$

132 of soil and $0.2 \mathrm{~kg}$ of perlite. The characteristics of the substrate were clay $202 \mathrm{~g} \mathrm{~kg}^{-1}$, silt 454

$133 \mathrm{~g} \mathrm{~kg}^{-1}$, sand $343 \mathrm{~g} \mathrm{~kg}^{-1}$, total $\mathrm{CaCO}_{3} 39 \mathrm{~g} \mathrm{~kg}^{-1}, \mathrm{pH}_{\mathrm{w}} 8.3, \mathrm{CEC}_{\text {Metson }} 15 \mathrm{cmol}_{+} \mathrm{kg}^{-1}$, organic C

$13410.4 \mathrm{~g} \mathrm{~kg}^{-1}$, total $\mathrm{N} 0.95 \mathrm{~g} \mathrm{~kg}^{-1}$, ammonium $\left(\mathrm{N}_{-} \mathrm{NH}_{4}{ }^{+}\right) 20 \mathrm{mg} \mathrm{kg}^{-1}$, nitrate $\left(\mathrm{N}_{-} \mathrm{NO}_{3}{ }^{-}\right) 39 \mathrm{mg} \mathrm{kg}^{-1}$.

135 The WHC of the substrate corresponded to $28 \%$ of gravimetric humidity. For simplicity,

136 substrate will be named herein as soil. The planting modalities of this experiment were: (i)

137 monoculture of wheat (W) (Triticum aestivum L. cv. Lennox) at a density of 4 plants per pot,

138 (ii) monoculture of white lupin (L) (Lupinus albus L. cv. Feodora) at a density of 2 plants per

139 pot, (iii) intercropping of both species (WL) at half of the density for each corresponding

140 monoculture (2 wheat and one lupin plants), and (iv) an unplanted soil (U). Each planted and

141 unplanted treatments was replicated 4 times. At maturity, plants (shoots and roots) were

142 harvested and the soil was carefully separated from the roots by gently shaking followed by

143 hand sorting and then kept at $4^{\circ} \mathrm{C}$ in the dark until microcosm experiment (16 weeks).

\subsection{Heat stress microcosm experiment}

A total of 128 microcosms were prepared (4 replicates $\mathrm{x} 4$ planting treatments $\mathrm{x} 2$

147 temperatures $\mathrm{x} 4$ sampling dates) containing $50 \mathrm{~g}$ of equivalent dry soil from greenhouse

148 experiment, and placed in $1-\mathrm{dm}^{3}$ glass jars hermetically sealed by a rubber gasket. Soils of

149 microcosms were rehydrated at $100 \%$ of the water holding capacity and pre incubated at $12^{\circ} \mathrm{C}$ 
150 for 5 days in order to ensure uniform initial experimental conditions. Afterwards, half of the

151 microcosms (64 samples) were incubated at $28^{\circ} \mathrm{C}$ and the remaining half at $48^{\circ} \mathrm{C}$,

152 corresponding to control (C) and heat stress (S) conditions, respectively. All microcosms were

153 placed into darkness in laboratory incubators (KBWF 720, Binder, Germany) with a precision

154 of $0.4{ }^{\circ} \mathrm{C}$. In order to i) avoid any drying-rewetting cycles during the experiment altering the

$155 \mathrm{C}$ and $\mathrm{N}$ cycles including nitrification (Fierer and Schimel, 2002) and ii) ensure precise

156 estimation of nitrification potential assays conducted with soil slurries (see section 2.3), we

157 kept soil moisture at $100 \%$ WHC. To ensure no variations of water regime in microcosms, a

$15820-\mathrm{cm}^{3}$ polypropylene container filled with water was placed in each sealed microcosm.

159 Microcosms were regularly weighted to check any soil moisture changes. After two days of

160 heat disturbance at $48^{\circ} \mathrm{C}$, the stressed microcosms were transferred back at $28^{\circ} \mathrm{C}$. Each

161 microcosm contained an $1 \mathrm{M} \mathrm{NaOH}$ trap for basal respiration determination (see section 2.3).

162 At each sampling date (T2, T7, T16 and T28 corresponding to 2, 7, 16 and 28 days after the

163 end of the heat stress), samples were immediately split into 4 subsamples for all subsequent

164 soil analyses (substrate-induced respiration (SIR), nitrification enzyme activity (NEA), soil

$165 \mathrm{NH}_{4}{ }^{+}$and $\mathrm{NO}_{3}{ }^{-}$measurements, and soil water content). Measurements of SIR and NEA were

166 performed on fresh soils within 2 days after sampling, whereas soil samples for mineral $\mathrm{N}$ 167 measurements were frozen $\left(-20^{\circ} \mathrm{C}\right)$ until analysis.

\subsection{Soil microbial and chemical analyses}

Basal respiration (BR) traps were collected and replaced at each sampling date. An

171 aliquot of $1-\mathrm{cm}^{3}$ of $\mathrm{NaOH}$ was back-titrated with $0.1 \mathrm{M} \mathrm{HCl}$, after adding $2.5-\mathrm{cm}^{3}$ of $\mathrm{BaCl}_{2}$

172 solution $(30 \%)$ to precipitate the $\mathrm{Na}_{2} \mathrm{CO}_{3}$ issued from soil $\mathrm{CO}_{2}$ respiration. Results of $\mathrm{BR}$

173 were expressed in $\mu \mathrm{g}$ C-CO $\mathrm{CO}_{2}$ day $^{-1} \mathrm{~g}^{-1}$ of dry soil. SIR measurements were performed on $10 \mathrm{~g}$

174 of equivalent dry soil according to Patra et al. (2005), in presence of glucose (1.2 mg C- 
175 glucose $\mathrm{g}^{-1}$ dry soil). A $\mathrm{CO}_{2}$ accumulation kinetic was measured using a gas chromatograph

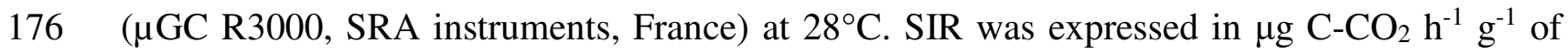

177 dry soil. NEA was measured with $3 \mathrm{~g}$ of equivalent dry soil according to Patra et al. (2005).

178 Briefly, a $\left(\mathrm{NH}_{4}\right)_{2} \mathrm{SO}_{4}$ solution $\left(50 \mu \mathrm{g} \mathrm{N}-\mathrm{NH}_{4}{ }^{+} \mathrm{g}^{-1}\right.$ dry soil $)$ was added to each soil sample.

179 Samples were placed at $28^{\circ} \mathrm{C}$, shaken at $140 \mathrm{rpm}$ to ensure aerobic conditions during 10

180 hours, and $\mathrm{NO}_{2}^{-}+\mathrm{NO}_{3}^{-}$production was measured every two hours using a photometer

181 (Smartchem 200, AMS Alliance, France). NEA was expressed in $\mu \mathrm{g}$ of $\mathrm{N}-\left(\mathrm{NO}_{2}{ }^{-}+\mathrm{NO}_{3}{ }^{-}\right) \mathrm{h}^{-1} \mathrm{~g}^{-1}$

182 of dry soil. Finally, soil ammonium $\left(\mathrm{N}^{-\mathrm{NH}_{4}}{ }^{+}\right)$and soil nitrate $\left(\mathrm{N}^{-\mathrm{NO}_{3}}{ }^{-}\right)$were extracted from a

183 soil:solution ratio of $1: 2$ with $1 \mathrm{M} \mathrm{KCl}$ solution after a $30 \mathrm{~min}$ of contact at $140 \mathrm{rpm}$, followed

184 by $30 \mathrm{~min}$ of rest. Supernatant were filtered at $0.45 \mu \mathrm{m}$ and mineral $\mathrm{N}$ concentrations were

185 estimated with an Analytical Discrete Multi-Chemistry Analyzer (AQ2, SEAL Analytical,

$186 \mathrm{UK}$ ). Soil mineral $\mathrm{N}$ content were expressed as $\mathrm{mg} \mathrm{N}-\mathrm{NH}_{4}{ }^{+}$and $\mathrm{mg} \mathrm{N}-\mathrm{NO}_{3}{ }^{-} \mathrm{kg}^{-1}$ of dry soil.

187

\subsection{Percentage change relative to control}

In order to investigate recovery rate, percentage change of values in stressed samples

190 relative to those in the controls, at each sampling date, were calculated as follows (Bérard et

191 al., 2011; Chaer et al., 2009):

192

193 relative change $(\%)=\left[\left(\frac{\mathrm{S}_{\mathrm{i}}}{\mathrm{C}_{\mathrm{i}}}\right)-1\right] \times 100$

195 where $S_{i}$ and $C_{i}$ are the variable values in the stressed and control soil samples, respectively, 196 at sampling date i (i.e. T2, T7, T16 or T28). 


\subsection{Soil microbial resistance and resilience indices}

To investigate only potential differences among soils with specific plant legacy (W, L, WL), unplanted (U) soil was not considered for calculation of resistance and resilience indices (see section 3.3). Resistance (RS) and resilience (RL) of soil microbial activities to a heat stress were assessed by the following indices (Orwin and Wardle, 2004):

$204 \quad \mathrm{RS}=1-\frac{2 \times\left|\mathrm{D}_{2}\right|}{\mathrm{C}_{2}+\left|\mathrm{D}_{2}\right|}$

where $\mathrm{D}_{2}$ is the difference between the values of the response variable (BR, SIR or NEA) in control $\left(\mathrm{C}_{2}\right)$ and stressed conditions $\left(\mathrm{S}_{2}\right), 2$ days after the end of the disturbance;

$R L=\frac{2 \times\left|D_{2}\right|}{\left|D_{2}\right|+|D x|}-1$

where $D_{x}$ is the difference between the control and disturbed soil on 7,16 or 28 days after the end of the disturbance. Both indices are bounded by -1 and +1 , where an index of 1 indicates full resistance (no effect of the disturbance on the response variable) or full resilience (same values of the response variable in control and stressed conditions). For resistance, an index value of 0 indicates either $100 \%$ decrease or increase in the response variable compared to control, while 217 a negative index represents a modification greater than $100 \%$ in the response variable 218 compared to the control (i.e. the soil has low resistance). In regard to resilience, an index of 0 indicates that the disturbed soil has either not recovered after the end of the disturbance (i.e. $D_{x}=D_{2}$ ) or that the stressed soil is different to the control by the same amount, but in the

221 opposite direction (i.e. $\mathrm{D}_{\mathrm{x}}=-\mathrm{D}_{2}$ ). A resilience index between 0 and 1 indicates that the 
response variable has not fully recovered, whereas a negative index value indicates that the absolute value of $\mathrm{D}_{\mathrm{x}}$ is higher than the absolute value of $\mathrm{D}_{2}$ (i.e. the soil has low resilience).

\subsection{Statistical analyses}

The effects of planting legacy (i.e. both planted (W, L, WL) and unplanted (U) modalities) and heat stress on all soil variables were tested for each sampling date by two-way ANOVA (planting legacy $\mathrm{x}$ heat stress). Afterwards, one-way ANOVA was performed in absence of interaction to test differences among treatments. The effect of specific plant legacy (i.e. only planted modalities $-\mathrm{W}, \mathrm{L}, \mathrm{WL}$ ) on resistance and resilience indices, as well as the effect of planting legacy on percentages of change in microbial activities relative to controls were also tested by one-way ANOVA, within each sampling date. Significant differences between means were tested by Tukey's multiple comparison tests $(p<0.05)$. Normality of residuals and homogeneity of variance were tested by the Shapiro and Levene's tests, respectively. When necessary, data for microbial activities were squared root-transformed. Principal component analysis (PCA) were performed with all chemical and microbial soil variables. Within a PCA, coordinates of the individuals on each axis were used for testing differences between groups (i.e. levels of a factor) by one-way ANOVA or Kruskal-Wallis tests in case of non-normality. Tukey's multiple comparison tests $(p<0.05)$ or Wilcoxon rank sum tests $(p<0.05)$ were then performed accordingly. Finally, a redundancy analysis (RDA) was performed to assess the effect of all soil microbial and chemical variables (SIR, NEA, BR, N-NO${ }_{3}^{-}$and $\mathrm{N}-\mathrm{NH}_{4}{ }^{+}$contents) on resistance (at $\mathrm{T} 2$ ) and resilience (at $\mathrm{T} 16$ ) indices. Statistical analyses were performed with R software v. 3.5.1 (R Core Team, 2018). Packages used for the ANOVA, Tukey's test, PCA and RDA analysis were: car, agricolae, FactoMineR and vegan, respectively. 


\section{Results}

3.1. Contrasted effects of planting and heat stress on microbial activities and soil mineral $\mathbf{N}$ content

The first two axes of the PCA performed on full data set (BR, SIR, NEA, N-NH${ }^{+}, \mathrm{N}-$ $\mathrm{NO}_{3}{ }^{-}$measurements for all sampling dates and stress conditions) explained $74.2 \%$ of the total

252 variance (Fig. 1). BR, N-NH${ }_{4}{ }^{+}, \mathrm{NEA}$ and $\mathrm{N}^{-\mathrm{NO}_{3}}{ }^{-}$are the major variables contributing to the 253 first axis while SIR was strongly and negatively correlated to the second axis (Table A.1). 254 Both planting legacy (W, L, WL, U) and sampling dates combined with control (C) and stress (S) conditions had a significant impact on values of samples (Kruskal-Wallis $p<0.001$; Table A.2 and A.3). Along axes 1 and 2, unplanted soil was significantly different from those with $\mathrm{W}, \mathrm{L}$ and WL legacies (Wilcoxon test, $p<0.001$ ), with centroids showing negative and positive values, respectively (Fig. 1a). Considering sampling dates combined with control and stress conditions (Fig. 1b), earlier dates were significantly distinct between control and heat stress. However, at these earlier dates, the unplanted stressed soils were closer to their controls, suggesting a greater resistance to heat stress. Interestingly, during the period of

262 resilience, the trajectories of the control and stressed soils evolved along the first axis, and at 263 the later dates (T16, T28) stressed and control soils were not significantly different from each other. At all dates combined, a clear difference was observed between stress and control conditions along the second axis (Wilcoxon test, $p<0.001$ ), with all centroids of the stressed 266 samples showing positive values, whereas centroids of controls showed negative values. 
Planting legacy was significant for BR values at the first two dates of measure $(p<$

0.001; Table 1 and Fig C.1). At these dates, L soils clearly differed from unplanted soils, with

L soils showing values 1.9-fold greater, when combining control and stress conditions. The planting legacy was still significant at T16, but no effect was observed at T28. An important effect of heat stress was also observed on BR values, particularly at T2 and T7 $(p<0.01$ and $p$ $<0.001$, respectively). At the two first dates, stressed soils presented values 1.35 -fold greater than control soils on average. At T16 the difference between stressed and control soils was lower, whereas no significant difference between stressed and control soils was observed at T28.

In regard to SIR, planting legacy $(p<0.001)$, heat stress $(p<0.001)$ and planting $\mathrm{x}$ stress interaction ( $p<0.01$ at T28 and $p<0.001$ at other dates) had a strong effect on SIR 281 values (Table 1 and Fig. C.2). Significant differences between planting legacies of control 282 soils were observed at all sampling dates. However, heat stress alleviated these differences.

283 For instance, at T2 (control), SIR means ranked as follows: $\mathrm{L}>\mathrm{WL}>\mathrm{W}=\mathrm{U}$, whereas no 284 differences were noticed after stress. One should note that L soils exhibited the greatest SIR 285 values, while unplanted soils presented the lowest. Conversely to BR, stressed conditions 286 exhibited a dramatic decrease of SIR activities compared to the controls, whatever the 287 sampling date. The most important difference was observed at the first date, when stressed 288 soils were 3.6-fold lower than controls. The L soils were particularly altered at the first date 289 because SIR activity were 5-fold lower than controls. This difference between stress and 290 control conditions was also present at the other dates, but decreased with time.

A very strong effect of planting legacy on NEA values was observed, whatever the 292 sampling date $(p<0.001$; Table 1 and Fig. C.3). Unplanted soils exhibited the greatest values 293 compared to planted soils (2.2- to 3.8-fold greater than W, L and WL). The heat stress effect 294 on NEA was particularly observed at T2 and T7 $(p<0.001)$. At these dates, a significant 
decrease in NEA values was observed between controls and stressed soils, but to a lesser 296 extent than that observed for SIR. At T16, heat stress had no effect on NEA, whereas at T28, a significant effect of heat stress $(p<0.05)$ and interaction of heat stress and planting legacy ( $p<0.001)$ were observed. An interesting dynamic was observed from T16 to T28, as NEA

values increased particularly for stressed (S) soils, and to a lesser extent for control (C) soils. 300 Indeed, at T28, there was a final ranking with L values becoming closer to U values (U_C > $\left.\mathrm{U} \_\mathrm{S}=\mathrm{L} \_\mathrm{S} \geq \mathrm{L} \_\mathrm{C}=\mathrm{W} \_\mathrm{S}=\mathrm{WL} \_\mathrm{S}>\mathrm{WL} \_\mathrm{C}=\mathrm{W} \_\mathrm{C}\right)$.

\subsection{Resistance and resilience of soil microbial activities}

Recovery rates are illustrated in Fig. 2. Just after heat disturbance (T2), SIR activity was severely altered $(-70 \%$, on average) compared to NEA $(-46 \%)$ and BR $(+36 \%)$. The most important decrease at $\mathrm{T} 2$ was observed for $\mathrm{L}$ soils, with a reduction of $79 \%$ in SIR relative to control samples. At this date, L soil also exhibited the largest increase in BR $(+59 \%)$ relative

to control samples. Conversely, for NEA, T2 showed the lowest decrease for the unplanted soil (-15\%). Focusing on the other dates for SIR, significant differences between percentages of change were only observed at T7, as follows: $\mathrm{U}>\mathrm{W}=\mathrm{WL}>\mathrm{L}$ (Table B.1). For NEA in T16, percentages of change for $\mathrm{WL}$ and $\mathrm{L}$, but not for $\mathrm{W}$ soils, switched from negative to positive. Significant differences between values were observed for NEA at T28. The W soils exhibited greater NEA values in stressed soils relative to controls and compared to WL and L

\section{4 (Table B.1).} Indices of resistance (RS) and resilience (RL) are presented in Table 2. Significant differences in resistance between soils were only observed for SIR $(p<0.05)$. The W soils exhibited the highest RS index, which was significantly different from L, but not from WL.

318 For resilience indices, significant differences between soils for NEA at T16 $(p<0.01)$ and for 319 SIR at T28 $(p<0.05)$ were observed. The RL indices for NEA of both WL and W soils were 
greater than that of $\mathrm{L}$ soils. The RL indices of $\mathrm{L}$ soils were negative at $\mathrm{T} 7, \mathrm{~T} 16$, and $\mathrm{T} 28$, meaning a very low resilience of NEA. For SIR at T28, the highest RL indices were found for L and WL soils.

The ordination plots of RDA performed on resistance (RS), at T2, and resilience (RL), only at T16, indices clearly discriminated the unplanted soil (Fig. 3 a,b). The resistance

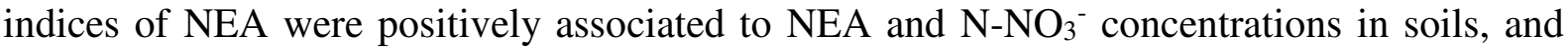

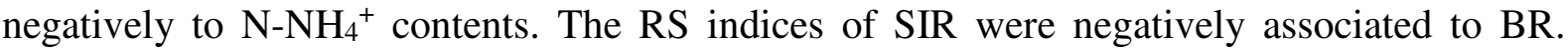
Considering resilience indices of NEA, these latter were negatively linked to NEA and N$\mathrm{NO}_{3}{ }^{-}$, whereas BR resilience indices were negatively linked to SIR and RL of SIR. Finally, considering soils with only specific plant legacies (W, L, WL), L soils slightly distinguished from the other soils on RDA plots for resistance, and strongly differed from the other soils for 331 resilience. Thus, these results confirmed percentages of change (Fig. 2) and RS and RL indices (Table 2). The L soils were clearly different, being characterized by lower RS of SIR and RL of NEA (Fig. 3 a,b).

\section{Discussion}

\subsection{Legacy effect of plants on soil microbial activities under control conditions}

Marked differences were observed between unplanted and planted soils, suggesting that plants were responsible for a legacy effect. Unplanted soils always exhibited greater

339 values of NEA than those for W, L and WL. As plants are able to shape N-related microbial communities (Moreau et al., 2015; Pivato et al., 2017), it occurred that all planted treatments had a negative legacy effect on the activity of nitrifiers. This negative legacy effect may be

342 attributed to the competition between plants and microorganisms for N (Cantarel et al., 2015;

343 Kuzyakov and $\mathrm{Xu}, 2013$; Xu et al., 2011). According to Schimel and Bennett (2004) plants

344 are effective competitors for ammonium which is also the substrate for nitrifiers, reducing 
their abundance and activity. Some plant morphological and/or physiological characteristics

346 can also affect the diversity of nitrifiers (Cantarel et al., 2015; Legay et al., 2014; Pommier et

347 al., 2018), or inhibit nitrification (Subbarao et al., 2012). According to these recent results,

348 one should hypothesize that nitrifiers community is shaped by the environment (Erguder et

349 al., 2009; Prosser and Nicol, 2012; Zhalnina et al., 2012), or by plant N-use strategy (Thion et

350 al., 2016). Thereby, we can reasonably suggest a plant legacy effect on nitrification. A great

351 contrast between unplanted and planted soils was also observed for BR and SIR values, with

352 lower values of $\mathrm{U}$ compared to $\mathrm{W}, \mathrm{L}$ and WL. This is consistent with Orwin and Wardle

353 (2005), who observed lower values of soil BR and SIR for bare soil compared to the planted

354 grass treatments. As large amounts of C-compounds can be released by roots as rhizodeposits,

355 e.g. sugars, organic acids, amino acids, mucilage, root or border cells (Kuzyakov and

356 Blagodatskaya, 2015; Philippot et al., 2013), an increase in microbial biomass and activities

357 (Tang et al., 2014) is expected in planted compared to unplanted soils.

358 Considering only planted soils, we also observed different legacy effects among the

359 modalities (W, L, WL), which is consistent with our first hypothesis. Indeed, except for the

360 first sampling date, greater values of NEA were observed for L soil, compared to W and WL,

361 i.e. a stronger legacy effect for lupin than wheat. Le Roux et al. (2013) also reported a

362 positive relationship between the presence of legumes and NEA, which was explained by the

363 build-up of nitrifying communities in response to greater $\mathrm{N}_{-} \mathrm{NH}_{4}{ }^{+}$availability in soils,

364 probably due to the release of $\mathrm{N}$ derived from Rhizodeposition (NdfR) by legumes (Duchene

365 et al., 2017). In addition, legumes are usually considered less competitive for soil mineral $\mathrm{N}$

366 compared to cereals, which could suggest a higher availability of mineral $\mathrm{N}$ in soils under

367 legumes (Mallarino and Wedin, 1990). L soils were also remarkable regarding to C-related

368 microbial variables, showing the greatest values of SIR whatever the date of measurement, as

369 well as the highest values of BR at T2 and T7. White lupin is well known to exude large 
370

quantities of organic anions, like citrate (Dissanayaka et al., 2015; Veneklaas et al., 2003; Wang et al., 2010), compared to cereals and other legumes (Wang et al., 2016). Such exudates may have promoted SIR and BR in our study. This positive legacy effect of white lupin on Crelated microbial variables compared to intercropped wheat and white lupin is however not in agreement with the commonly observed positive effect of plant diversity on soil microbial biomass and respiration (Chen et al., 2019; Eisenhauer et al., 2017; Tang et al., 2014). Accordingly, one should note that legume legacies may be further investigated in agroecosystems in order to decipher their potential role in rotation or in intercropping.

\subsection{Effects of experimental conditions on C-related microbial activities: Basal} Respiration and Substrate-Induced Respiration

Amongst response variables, SIR was the most affected by heat stress (T2). Samples affected by stress presented reductions varying from $65 \%$ to $79 \%$ relative to controls. As SIR may be considered as a proxy of the active microbial biomass (Anderson and Domsch, 1978; Orwin and Wardle, 2005), these results suggest a dramatic decrease in microbial biomass by the disturbance. The mortality of temperature-sensitive microbes has been observed in other studies where heat and combined heat-drought stresses were applied (Bérard et al., 2011; Guillot et al., 2019; Hamdi et al., 2011). The effect of temperature on SIR activities was also evident when comparing the heat stress responses of planted soils. In our study, L soils presented the highest values of SIR activity under control conditions, but after heat stress, SIR activity decreased to levels comparable to the other treatments. Then, we concluded that an important microbial biomass in $\mathrm{L}$ soils did not confer a better resistance to the heat disturbance. This finding was consistent with Guillot et al. (2019), who observed that Mediterranean soils exhibiting the highest microbial biomass were not systematically 
associated with a higher resistance. Conversely, W soils which exhibited the lowest values of

395 SIR, presented the greatest resistance index (Table 2), which suggests a greater proportion of more heat-tolerant microbes within this modality. A weaker plant legacy effect on C-related microbial activities due to inherent quality of this type of soil (Salomé et al., 2014) was

398 expected. However, recent studies pointed out that combined heat and drought stresses were 399 able to significantly alter the microbial biomass (Bérard et al., 2011; Guillot et al., 2019), or 400 acclimate of soil communities to heat waves (Bérard et al., 2012) in Mediterranean soils. In 401 our study, the plant-induced effects may be partly due to a soil microbes protection by plant 402 liberation of exopolysaccharides (Kumar and Verma, 2018). Soils with L and WL legacies 403 presented the highest resilience indices and recovery rates for SIR. The rapid progression of L 404 and WL soils over time reduced final differences between these soils and W at T28 (Fig. 2). 405 Despite strongly affected by heat stress, the better resilience of L and WL suggest that heat 406 tolerant microbes rapidly proliferated. The greater resilience of $\mathrm{L}$ soils could be attributed to a 407 greater $\mathrm{C}$ availability derived from death of the most sensitive microorganisms (Bérard et al., 408 2015), but also by transformation of soil organic matter as induced by the elevated 409 temperature (Bérard et al., 2011; Hamdi et al., 2011). It should be noted that a positive 410 priming effect due to lupin legacy may also contribute to $\mathrm{C}$ availability in $\mathrm{L}$ soils conferring a 411 greater resilience of L and WL (Wang et al., 2016).

413 4.3. Effects of experimental conditions on N-related microbial activities: Nitrification 414 Enzyme Activity (NEA)

NEA was affected by heat stress, but to a lesser extent than SIR, while comparable to 416 BR (Fig. 2). Both temperature and moisture are considered as major environmental factors 417 affecting microbial activities and structure. Considerable debate stands in literature about 418 optimal temperature for soil nitrifiers (Taylor et al., 2017) with scarce studies dealing with the 
effect of nitrification rate at temperatures higher than $40^{\circ} \mathrm{C}$. Indigenous nitrifiers have

420 different optimal temperatures depending on native region (Avrahami and Conrad, 2003).

421 Albeit $>40^{\circ} \mathrm{C}$ temperatures may be experienced in Mediterranean regions, the duration of 422 continuous heat stress, i.e. 2 days, is not reproducible under Mediterranean field conditions. 423 French regulation for Mediterranean region defines severe heat waves as a period lasting 2-3 424 days, and characterized by elevated temperature $>35^{\circ} \mathrm{C}$ and $>21^{\circ} \mathrm{C}$ during day and night 425 respectively. Thus, night cooling decreases temperature stress even during severe heat waves, 426 which was not the case during our experiment. Then, 2 days on continuous applied $48^{\circ} \mathrm{C}$ 427 temperature have to be considered as a stress while not fully realistic of field conditions. One 428 should note our moisture content of soils (100\% of WHC) during the experiment. Nitrification 429 rate is affected by drying-rewetting cycles (Fierer and Schimel, 2002) such as mineralization 430 (Zhang et al., 2017). Fierer and Schimel (2002) depicted an increase of nitrification potentials 431 in frequently drying-rewetting stress treatments. In their experiment, they do not succeed to 432 attribute any changes of nitrification rates when soil moisture increased from $35 \%$ to $50 \%$ 433 WHC. Mathieu et al. (2006) estimated no significant differences of nitrification rates using $434{ }^{15} \mathrm{~N}$ tracer under $150 \%$ WHC (saturated) and $75 \%$ of WHC (unsaturated conditions) in soil 435 incubations with $2 \mathrm{~mm}$ aggregates. We thus assumed that our uncommon WHC did not alter 436 potential nitrification rates. However, possible restricted oxygen availability due to $\mathrm{O}_{2}$ 437 consumption by mineralization during the incubation period could be pointed out. A $\mathrm{O}_{2}$ 438 restriction may finally alter nitrifier's community growth rate and activity at earlier dates of 439 our experiment. As nitrification potentials are estimated under shaking to provide aeration, 440 oxygen limitation at earlier dates (T2 and T7) may have been less pronounced than at T16. 441 One should note that our goal was to test if planted treatments conferred different legacy 442 effects on potential NEA in response to a heat disturbance. Despite discussed limitations of 443 our experiment, we discussed significant differences while keeping in mind potential 
444 limitations of field transposition of our results. We demonstrated that WL legacy exhibited 445 comparable resistance and resilience than those with W legacy. The WL soil was the less 446 affected by the heat stress initially (T2), with a reduction by only $31 \%$ in NEA relative to the 447 control (Fig. 2), but this trend was not reflected on resistance indices, probably due to the high 448 variability among replicates. However, in terms of resilience, at T16, significant differences 449 between indices were verified, with WL and W soils exhibiting the highest resilience indices. 450 Pivato et al. (2017) estimated a greater abundance of nitrifiers in soils from plant associations, 451 whereas Le Roux et al. (2013) and Zhang et al. (2015) reported a negative effect of plant 452 richness on the abundance of ammonia oxidizers. These latter articles suggested that plant 453 identity rather than plant diversity can affect nitrifier community abundances. Considering 454 gene-based associated groups of nitrifiers namely Ammonia Oxidizing Archaea and Bacteria 455 (AOA and AOB), Thion et al. (2016) estimated greater AOA abundance in the rhizosphere of exploitative grass species, like wheat. Moreover, Taylor et al. (2017) considered that AOA 457 nitrifiers are more tolerant to higher temperatures. Thus, better resilience in planting 458 modalities containing wheat could be attributed to these published results. Finally, one should 459 also note the interesting NEA dynamic observed at later stages in our study. A strong increase 460 in NEA activities of all soils was observed at T28, compared to T16, for both control and heat 461 stress conditions (Table 1). Such increase in NEA at this final date could be explained by a 462 "boost" in the activities of nitrifiers after 30 days of incubation in optimal conditions. Since 463 the growth rates of nitrifiers are recognized to be relatively slow (Robertson and Groffman, 464 2015; Wertz et al., 2007), the interpretation of NEA resilience is then highly dependent of the 465 final experimental dates. Accordingly, one should note that individual properties of 466 microorganisms like dormancy, plasticity and growth rate (Shade et al., 2012) are also 467 important components of resistance and resilience of soil microbial communities. 


\section{Conclusions}

Adaptation to climate change of Mediterranean soils regularly exposed to heat waves may be possible through plant legacy effects. Intercropping confers more stability of soil microbial activities compared to single crop species when both $\mathrm{C}$ and $\mathrm{N}$ are investigated together due to individual benefits of each plant type. Finally, additional studies are essential to investigate if, i) prolonged plant presence will allow a more persistent effect on soils, and if ii) longer period of incubation would be able to detect full recovery of soil microbial activities over time. These results can provide useful information for designing cropping systems, in particular crop rotations and/or intercropping to capitalize on different legacy effects of various crops.

\section{Acknowledgements}

This work was supported by Centre Mondial de l'Innovation - CMI (Roullier Group). Authors warmly acknowledge Dr. Jean-Claude Yvin and Dr. Mustapha Arkoun from CMI for their support during this project. Authors want to thank Mrs. Béatrice Trinkler for her technical support during incubation period and for soil chemical analyses. We also thank the “Activités Microbiennes dans l'Environnement” platform (AME platform, Université Lyon1,

UMR 5557) and particularly Mr. Jonathan Gervaix for supervising and measuring SIR and NEA microbial activities with Ms. Marie Seiller. We are also grateful to the anonymous reviewers for their comments improving our article.

\section{References}


Avrahami, S., and Conrad, R. (2003). Patterns of community change among ammonia oxidizers in meadow soils upon long-term incubation at different temperatures. Appl. Environ. Microbiol. 69, 6152-6164.

Bailey, J. K., and Schweitzer, J. A. (2016). The rise of plant-soil feedback in ecology and evolution. Functional Ecology 30, 1030-1031.

Bérard, A., Ben Sassi, M., Kaisermann, A., and Renault, P. (2015). Soil microbial community responses to heat wave components: drought and high temperature. Climate Research 66, 243-264.

Bérard, A., Ben Sassi, M., Renault, P., and Gros, R. (2012). Severe drought-induced community tolerance to heat wave. An experimental study on soil microbial processes. Journal of Soils and Sediments 12, 513-518.

Bérard, A., Bouchet, T., Sévenier, G., Pablo, A. L., and Gros, R. (2011). Resilience of soil microbial communities impacted by severe drought and high temperature in the context of Mediterranean heat waves. European Journal of Soil Biology 47, 333-342.

Brooker, R. W., Bennett, A. E., Cong, W.-F., Daniell, T. J., George, T. S., Hallett, P. D., Hawes, C., Iannetta, P. P. M., Jones, H. G., Karley, A. J., Li, L., McKenzie, B. M., Pakeman, R. J., Paterson, E., Schöb, C., Shen, J., Squire, G., Watson, C. A., Zhang, C., Zhang, F., Zhang, J., and White, P. J. (2015). Improving intercropping: a synthesis of research in agronomy, plant physiology and ecology. New Phytologist 206, 107117.

Cantarel, A. A. M., Pommier, T., Desclos-Theveniau, M., Diquélou, S., Schloter, M., and Poly, F. (2015). Using plant traits to explain plant-microbe relationships involved in nitrogen acquisition. Ecology 96(3), 788-799.

Chaer, G., Fernandes, M., Myrold, D., and Bottomley, P. (2009). Comparative resistance and resilience of soil microbial communities and enzyme activities in adjacent native forest and agricultural soils. Microb Ecol 58, 414-24.

Chen, C., Chen, H. Y., Chen, X., and Huang, Z. (2019). Meta-analysis shows positive effects of plant diversity on microbial biomass and respiration. Nature communications $\mathbf{1 0}$, 1332.

Cong, W. F., Hoffland, E., Li, L., Six, J., Sun, J. H., Bao, X. G., Zhang, F. S., and Van Der Werf, W. (2015). Intercropping enhances soil carbon and nitrogen. Glob Chang Biol 21, 1715-26.

de Vries, F. T., Liiri, M. E., Bjørnlund, L., Setälä, H. M., Christensen, S., and Bardgett, R. D. (2012). Legacy effects of drought on plant growth and the soil food web. Oecologia 170, 821-833.

Dennis, P. G., Miller, A. J., and Hirsch, P. R. (2010). Are root exudates more important than other sources of rhizodeposits in structuring rhizosphere bacterial communities? FEMS microbiology ecology 72, 313-327.

Dissanayaka, D. M. S., Maruyama, H., Masuda, G., and Wasaki, J. (2015). Interspecific facilitation of $\mathrm{P}$ acquisition in intercropping of maize with white lupin in two contrasting soils as influenced by different rates and forms of P supply. Plant and Soil 390, 223-236.

Doré, T., Makowski, D., Malézieux, E., Munier-Jolain, N., Tchamitchian, M., and Tittonell, P. (2011). Facing up to the paradigm of ecological intensification in agronomy: 

210.

Duchene, O., Vian, J.-F., and Celette, F. (2017). Intercropping with legume for agroecological cropping systems: Complementarity and facilitation processes and the importance of soil microorganisms. A review. Agriculture, Ecosystems \& Environment 240, 148161.

Eisenhauer, N., Lanoue, A., Strecker, T., Scheu, S., Steinauer, K., Thakur, M. P., and Mommer, L. (2017). Root biomass and exudates link plant diversity with soil bacterial and fungal biomass. Scientific reports 7, 44641.

Erguder, T. H., Boon, N., Wittebolle, L., Marzorati, M., and Verstraete, W. (2009). Environmental factors shaping the ecological niches of ammonia-oxidizing archaea. FEMS microbiology reviews 33, 855-869.

Fierer, N., and Schimel, J. P. (2002). Effects of drying-rewetting frequency on soil carbon and nitrogen transformations. Soil Biology and Biochemistry 34, 777-787.

Griffiths, B. S., and Philippot, L. (2013). Insights into the resistance and resilience of the soil microbial community. FEMS Microbiol Rev 37, 112-29.

Grman, E., and Suding, K. N. (2010). Within - year soil legacies contribute to strong priority effects of exotics on native California grassland communities. Restoration Ecology 18, 664-670.

Guillot, E., Hinsinger, P., Dufour, L., Roy, J., and Bertrand, I. (2019). With or without trees: Resistance and resilience of soil microbial communities to drought and heat stress in a Mediterranean agroforestry system. Soil Biology \& Biochemistry 129, 122-135.

Hamdi, S., Chevallier, T., Ben Aïssa, N., Ben Hammouda, M., Gallali, T., Chotte, J.-L., and Bernoux, M. (2011). Short-term temperature dependence of heterotrophic soil respiration after one-month of pre-incubation at different temperatures. Soil Biology and Biochemistry 43, 1752-1758.

Hinsinger, P., Bengough, A. G., Vetterlein, D., and Young, I. M. (2009). Rhizosphere: biophysics, biogeochemistry and ecological relevance. Plant and soil 321, 117-152.

Hunter, P. J., Teakle, G., and Bending, G. D. (2014). Root traits and microbial community interactions in relation to phosphorus availability and acquisition, with particular reference to Brassica. Frontiers in plant science 5, 27.

Kumar, A., and Verma, J. P. (2018). Does plant-Microbe interaction confer stress tolerance in plants: A review? Microbiological research 207, 41-52.

Kuzyakov, Y., and Blagodatskaya, E. (2015). Microbial hotspots and hot moments in soil: concept \& review. Soil Biology and Biochemistry 83, 184-199.

Kuzyakov, Y., and Xu, X. (2013). Competition between roots and microorganisms for nitrogen: mechanisms and ecological relevance. New Phytologist 198, 656-669.

Lange, M., Eisenhauer, N., Sierra, C. A., Bessler, H., Engels, C., Griffiths, R. I., MelladoVázquez, P. G., Malik, A. A., Roy, J., Scheu, S., Steinbeiss, S., Thomson, B. C., Trumbore, S. E., and Gleixner, G. (2015). Plant diversity increases soil microbial activity and soil carbon storage. Nature Communications $\mathbf{6}$.

Le Roux, X., Schmid, B., Poly, F., Barnard, R. L., Niklaus, P. A., Guillaumaud, N., Habekost, M., Oelmann, Y., Philippot, L., Salles, J. F., Schloter, M., Steinbeiss, S., and Weigelt, A. (2013). Soil environmental conditions and microbial build-up mediate the effect of 
plant diversity on soil nitrifying and denitrifying enzyme activities in temperate grasslands. PLoS One 8, e61069.

583

584

585

586

587

588

589

590

591

592

593

594

595

596

597

598

599

600

601

602

603

604

605

606

607

608

609

610

611

612

613

614

615

616

617

618

619

620

621

622

623

Legay, N., Baxendale, C., Grigulis, K., Krainer, U., Kastl, E., Schloter, M., Bardgett, R. D., Arnoldi, C., Bahn, M., and Dumont, M. (2014). Contribution of above-and belowground plant traits to the structure and function of grassland soil microbial communities. Annals of botany 114, 1011-1021.

Li, X., Jousset, A., de Boer, W., Carrión, V. J., Zhang, T., Wang, X., and Kuramae, E. E. (2018). Legacy of land use history determines reprogramming of plant physiology by soil microbiome. The ISME journal, 1.

Malézieux, E., Crozat, Y., Dupraz, C., Laurans, M., Makowski, D., Ozier-Lafontaine, H., Rapidel, B., Tourdonnet, S., and Valantin-Morison, M. (2009). Mixing plant species in cropping systems: concepts, tools and models. A review. Agronomy for Sustainable Development 29, 43-62.

Mallarino, A., and Wedin, W. (1990). Effect of species and proportion of legume on herbage yield and nitrogen concentration of legume - grass mixtures. Grass and Forage Science 45, 393-402.

Mathieu, O., Henault, C., Leveque, J., Baujard, E., Milloux, M. J., and Andreux, F. (2006). Quantifying the contribution of nitrification and denitrification to the nitrous oxide flux using 15N tracers. Environ Pollut 144, 933-40.

Mooshammer, M., Hofhansl, F., Frank, A. H., Wanek, W., Hämmerle, I., Leitner, S., Schnecker, J., Wild, B., Watzka, M., and Keiblinger, K. M. (2017). Decoupling of microbial carbon, nitrogen, and phosphorus cycling in response to extreme temperature events. Science advances 3, e1602781.

Moreau, D., Pivato, B., Bru, D., Busset, H., Deau, F., Faivre, C., Matejicek, A., Strbik, F., Philippot, L., and Mougel, C. (2015). Plant traits related to nitrogen uptake influence plant-microbe competition. Ecology 96(8), 2300-2310.

Orwin, K. H., and Wardle, D. A. (2004). New indices for quantifying the resistance and resilience of soil biota to exogenous disturbances. Soil Biology and Biochemistry 36, 1907-1912.

Orwin, K. H., and Wardle, D. A. (2005). Plant Species Composition Effects on Belowground Properties and the Resistance and Resilience of the Soil Microflora to a Drying Disturbance. Plant and Soil 278, 205-221.

Patra, A., Abbadie, L., Clays-Josserand, A., Degrange, V., Grayston, S., Loiseau, P., Louault, F., Mahmood, S., Nazaret, S., and Philippot, L. (2005). Effects of grazing on microbial functional groups involved in soil N dynamics. Ecological Monographs 75, 65-80.

Philippot, L., Raaijmakers, J. M., Lemanceau, P., and van der Putten, W. H. (2013). Going back to the roots: the microbial ecology of the rhizosphere. Nat Rev Microbiol 11, 789-99.

Pivato, B., Bru, D., Busset, H., Deau, F., Matejicek, A., Philippot, L., and Moreau, D. (2017). Positive effects of plant association on rhizosphere microbial communities depend on plant species involved and soil nitrogen level. Soil Biology and Biochemistry 114, 1-4.

Pommier, T., Cantarel, A. A., Grigulis, K., Lavorel, S., Legay, N., Baxendale, C., Bardgett, R. D., Bahn, M., Poly, F., and Clément, J. C. (2018). The added value of including key 
microbial traits to determine nitrogen - related ecosystem services in managed grasslands. Journal of applied ecology 55, 49-58.

Prosser, J. I., and Nicol, G. W. (2012). Archaeal and bacterial ammonia-oxidisers in soil: the quest for niche specialisation and differentiation. Trends Microbiol 20, 523-31.

R Core Team (2018). R: A Language and Environment for Statistical Computing. R Foundation for Statistical Computing, Vienna, Austria.

Robertson, G. P., and Groffman, P. M. (2015). Nitrogen Transformations. In "Soil microbiology, ecology and biochemistry" (E. A. Paul, ed.), pp. 421-446. Academic Press, Burlington, Massachussetts, USA.

Salomé, C., Coll, P., Lardo, E., Villenave, C., Blanchart, E., Hinsinger, P., Marsden, C., and Le Cadre, E. (2014). Relevance of use-invariant soil properties to assess soil quality of vulnerable ecosystems: The case of Mediterranean vineyards. Ecological Indicators 43, 83-93.

Schimel, J. P., and Bennett, J. (2004). Nitrogen mineralization: challenges of a changing paradigm. Ecology 85, 591-602.

Shade, A., Peter, H., Allison, S. D., Baho, D. L., Berga, M., Burgmann, H., Huber, D. H., Langenheder, S., Lennon, J. T., Martiny, J. B., Matulich, K. L., Schmidt, T. M., and Handelsman, J. (2012). Fundamentals of microbial community resistance and resilience. Front Microbiol 3, 417.

Strecker, T., Macé, O. G., Scheu, S., and Eisenhauer, N. (2016). Functional composition of plant communities determines the spatial and temporal stability of soil microbial properties in a long-term plant diversity experiment. Oikos 125, 1743-1754.

Subbarao, G., Sahrawat, K., Nakahara, K., Ishikawa, T., Kishii, M., Rao, I., Hash, C., George, T., Rao, P. S., and Nardi, P. (2012). Biological nitrification inhibition-a novel strategy to regulate nitrification in agricultural systems. In "Advances in agronomy", Vol. 114, pp. 249-302. Elsevier.

Tang, X., Bernard, L., Brauman, A., Daufresne, T., Deleporte, P., Desclaux, D., Souche, G., Placella, S. A., and Hinsinger, P. (2014). Increase in microbial biomass and phosphorus availability in the rhizosphere of intercropped cereal and legumes under field conditions. Soil Biology and Biochemistry 75, 86-93.

Tang, X., Placella, S. A., Daydé, F., Bernard, L., Robin, A., Journet, E.-P., Justes, E., and Hinsinger, P. (2016). Phosphorus availability and microbial community in the rhizosphere of intercropped cereal and legume along a P-fertilizer gradient. Plant and Soil 407, 119-134.

Taylor, A. E., Giguere, A. T., Zoebelein, C. M., Myrold, D. D., and Bottomley, P. J. (2017). Modeling of soil nitrification responses to temperature reveals thermodynamic differences between ammonia-oxidizing activity of archaea and bacteria. ISME J 11, 896-908.

Thion, C., and Prosser, J. I. (2014). Differential response of nonadapted ammonia-oxidising archaea and bacteria to drying-rewetting stress. FEMS Microbiol Ecol 90, 380-9.

Thion, C. E., Poirel, J. D., Cornulier, T., De Vries, F. T., Bardgett, R. D., and Prosser, J. I. (2016). Plant nitrogen-use strategy as a driver of rhizosphere archaeal and bacterial ammonia oxidiser abundance. FEMS Microbiol Ecol 92. 
van der Putten, W. H., Bardgett, R. D., Bever, J. D., Bezemer, T. M., Casper, B. B., Fukami, T., Kardol, P., Klironomos, J. N., Kulmatiski, A., Schweitzer, J. A., Suding, K. N., Van de Voorde, T. F. J., Wardle, D. A., and Hutchings, M. (2013). Plant-soil feedbacks: the past, the present and future challenges. Journal of Ecology 101, 265276.

van der Putten, W. H., Bradford, M. A., Pernilla Brinkman, E., van de Voorde, T. F., and Veen, G. (2016). Where, when and how plant-soil feedback matters in a changing world. Functional Ecology 30, 1109-1121.

Veneklaas, E. J., Stevens, J., Cawthray, G. R., Turner, S., Grigg, A. M., and Lambers, H. (2003). Chickpea and white lupin rhizosphere carboxylates vary with soil properties and enhance phosphorus uptake. Plant and Soil 248, 187-197.

Wang, B. L., Tang, X. Y., Cheng, L. Y., Zhang, A. Z., Zhang, W. H., Zhang, F. S., Liu, J. Q., Cao, Y., Allan, D. L., Vance, C. P., and Shen, J. B. (2010). Nitric oxide is involved in phosphorus deficiency-induced cluster-root development and citrate exudation in white lupin. New Phytologist 187, 1112-1123.

Wang, X., Tang, C., Severi, J., Butterly, C. R., and Baldock, J. A. (2016). Rhizosphere priming effect on soil organic carbon decomposition under plant species differing in soil acidification and root exudation. New Phytologist 211, 864-873.

Wertz, S., Degrange, V., Prosser, J. I., Poly, F., Commeaux, C., Guillaumaud, N., and Le Roux, X. (2007). Decline of soil microbial diversity does not influence the resistance and resilience of key soil microbial functional groups following a model disturbance. Environ Microbiol 9, 2211-9.

Xu, X., Ouyang, H., Richter, A., Wanek, W., Cao, G., and Kuzyakov, Y. (2011). Spatiotemporal variations determine plant-microbe competition for inorganic nitrogen in an alpine meadow. Journal of Ecology 99, 563-571.

Zak, D. R., Holmes, W. E., White, D. C., Peacock, A. D., and Tilman, D. (2003). Plant diversity, soil microbial communities, and ecosystem function: are there any links? Ecology 84, 2042-2050.

Zhalnina, K., de Quadros, P. D., Camargo, F. A., and Triplett, E. W. (2012). Drivers of archaeal ammonia-oxidizing communities in soil. Front Microbiol 3, 210.

Zhang, N. N., Sun, Y. M., Wang, E. T., Yang, J. S., Yuan, H. L., and Scow, K. M. (2015). Effects of intercropping and Rhizobial inoculation on the ammonia-oxidizing microorganisms in rhizospheres of maize and faba bean plants. Applied Soil Ecology 85, 76-85.

Zhang, W., Liang, C., Kao-Kniffin, J., He, H., Xie, H., and Zhang, X. (2017). Effects of drying and wetting cycles on the transformations of extraneous inorganic $\mathrm{N}$ to soil microbial residues. Scientific reports 7, 9477. 
Fig. 1. Principal component analysis (PCA) performed on basal respiration (BR), substrateinduced respiration (SIR), nitrification enzyme activity (NEA) and soil mineral $\mathrm{N}$ content as nitrate $\left(\mathrm{N}^{-\mathrm{NO}_{3}}{ }^{-}\right)$and ammonium $\left(\mathrm{N}-\mathrm{NH}_{4}{ }^{+}\right)$. Symbols stand for planting legacy (W - wheat, $\mathrm{L}$ - lupin, WL - wheat + lupin, U - unplanted) (a) and sampling dates (T2, T7, T16 and T28 2, 7, 16 and 28 days after the end of the heat stress) within control (C) and heat stress (S) conditions (b). Centroids are represented by larger symbols.

Fig. 2. Percentages of change in microbial activities (BR - basal respiration, SIR - substrateinduced respiration, NEA - nitrification enzyme activity) relative to controls along all sampling dates after the end of the heat stress (T2, T7, T16, T28). Symbols represent planting legacy (W - wheat, L - white lupin, WL - wheat + lupin, U - unplanted). Vertical bars indicate standard errors $(n=4)$. Asterisks indicate significant differences between planting legacies within a sampling date (one-way ANOVA, followed by a Tukey post hoc test ( $p<$ $0.05)$ ).

Fig. 3. Redundancy analysis (RDA) based on resistance (RS) (a) or resilience (RL) (b) indices of basal respiration (BR), substrate-induced respiration (SIR) and nitrification enzyme activity (NEA), constrained by BR, SIR, NEA, as well as soil mineral $\mathrm{N}$ content as nitrate $\left(\mathrm{N}_{-} \mathrm{NO}_{3}{ }^{-}\right)$ and ammonium $\left(\mathrm{N}-\mathrm{NH}_{4}{ }^{+}\right)$. Resistance indices were calculated for $\mathrm{T} 2$, whereas resilience indices were calculated for T16 ( 2 and 16 days after the end of the heat stress). Groups of planting legacies are represented by $\mathrm{W}$ (wheat) in blue, L (lupin) in orange, WL (wheat + lupin) in green and $\mathrm{U}$ (unplanted) in red. The RDA was performed on center-reduced matrix.

Table 1. Basal respiration (BR - in $\mu \mathrm{g} \mathrm{C}-\mathrm{CO}_{2}$ day $^{-1} \mathrm{~g}^{-1}$ dry soil), substrate-induced respiration ( $\mathrm{SIR}$ - in $\mu \mathrm{g} \mathrm{C}-\mathrm{CO}_{2} \mathrm{~h}^{-1} \mathrm{~g}^{-1}$ dry soil) and nitrification enzyme activity (NEA - in $\mu \mathrm{g} \mathrm{N}-\mathrm{NO}_{2}{ }^{-}+$ $\mathrm{N}-\mathrm{NO}_{3}{ }^{-} \mathrm{h}^{-1} \mathrm{~g}^{-1}$ dry soil) of each planting legacy (W - wheat, $\mathrm{L}$ - lupin, WL - wheat+lupin, $\mathrm{U}$ - unplanted), within control and stress conditions, for each sampling date after the end of the heat stress (T2, T7, T16, T28). Values are the means of four replicates $(n=4)$. Thresholds of probability of the two-way ANOVA (Planting x Stress) are indicated at the top of each variable-related data set. When significant interaction between factors (Planting x Stress) is present, different bold letters represent significant differences between 8 means (i.e. control and heat stress conditions combined; Tukey post hoc test $(p<0.05)$ ). Different lowercase letters represent significant differences within a single column, whereas different uppercase letters represent either significant differences between stress conditions (Control vs Stress), or between planting legacies with control and stress conditions combined (Tukey post hoc test ( $p$ $<0.05)$ ).

Table 2. Indices of resistance and resilience based on basal respiration (BR), substrateinduced respiration (SIR) and nitrification enzyme activity (NEA) for each specific plant legacy (W - wheat, L - lupin, WL - wheat+lupin). Resistance indices were calculated on T2 date ( 2 days after the end of the heat stress), whereas resilience indices were calculated on T7, T16 and T28 dates of measure (7,16 and 28 days after the end of the heat stress). Values are the means of four replicates $(n=4)$. Probabilities of the one-way ANOVA are indicated at the bottom of each variable-related data set. Different letters represent significant differences within a column (Tukey post hoc test $(p<0.05)$ ). 


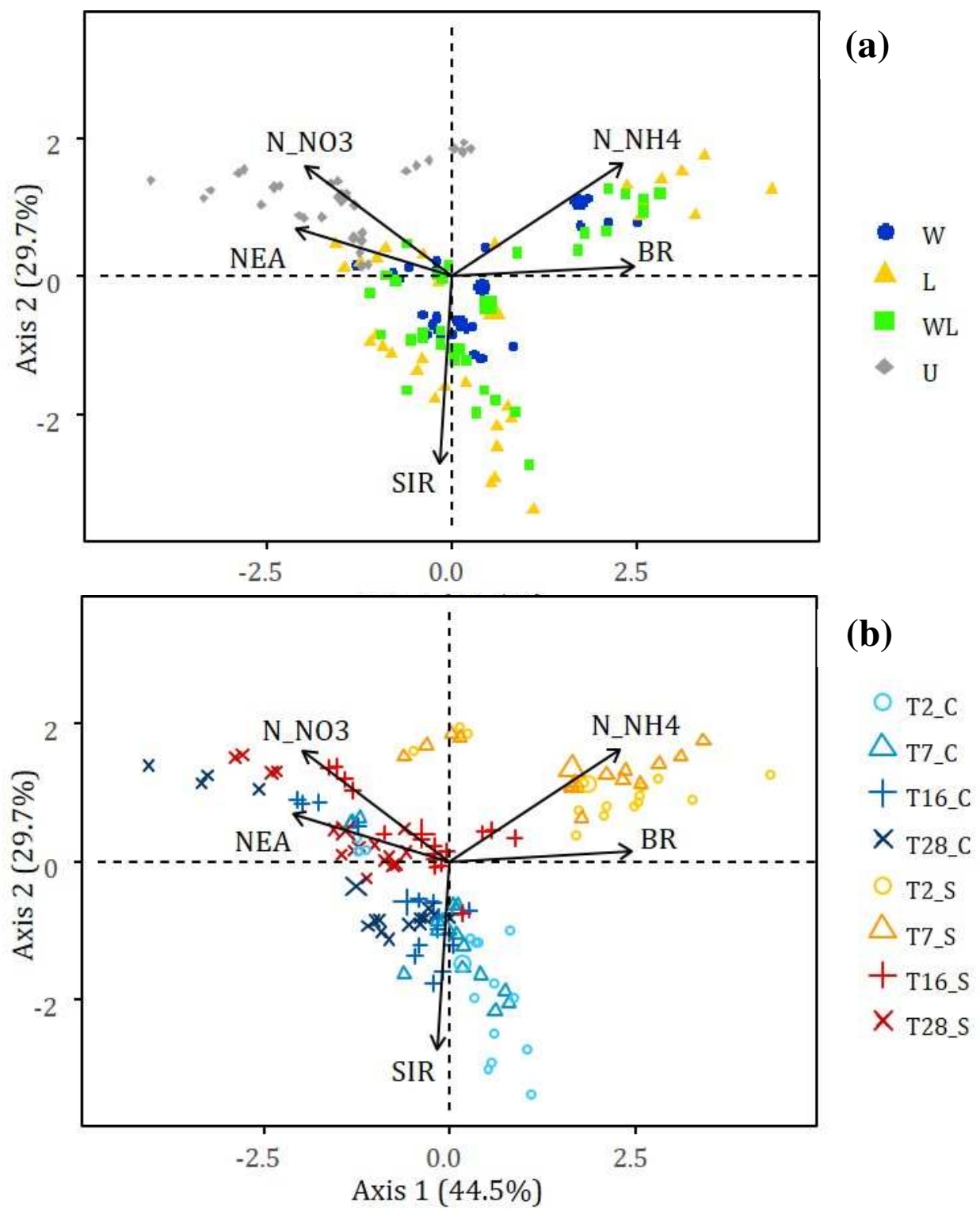

Fig. 1. Principal component analysis (PCA) performed on basal respiration (BR), substrate-induced respiration (SIR), nitrification enzyme activity (NEA) and soil mineral $\mathrm{N}$ content as nitrate $\left(\mathrm{N}-\mathrm{NO}_{3}{ }^{-}\right)$and ammonium $\left(\mathrm{N}-\mathrm{NH}_{4}{ }^{+}\right)$. Symbols stand for planting legacy (W - wheat, L - lupin, WL - wheat + lupin, $\mathrm{U}$ - unplanted) (a) and sampling dates (T2, T7, T16 and T28 - 2, 7, 16 and 28 days after the end of the heat stress) within control (C) and heat stress (S) conditions (b). Centroids are represented by larger symbols. 

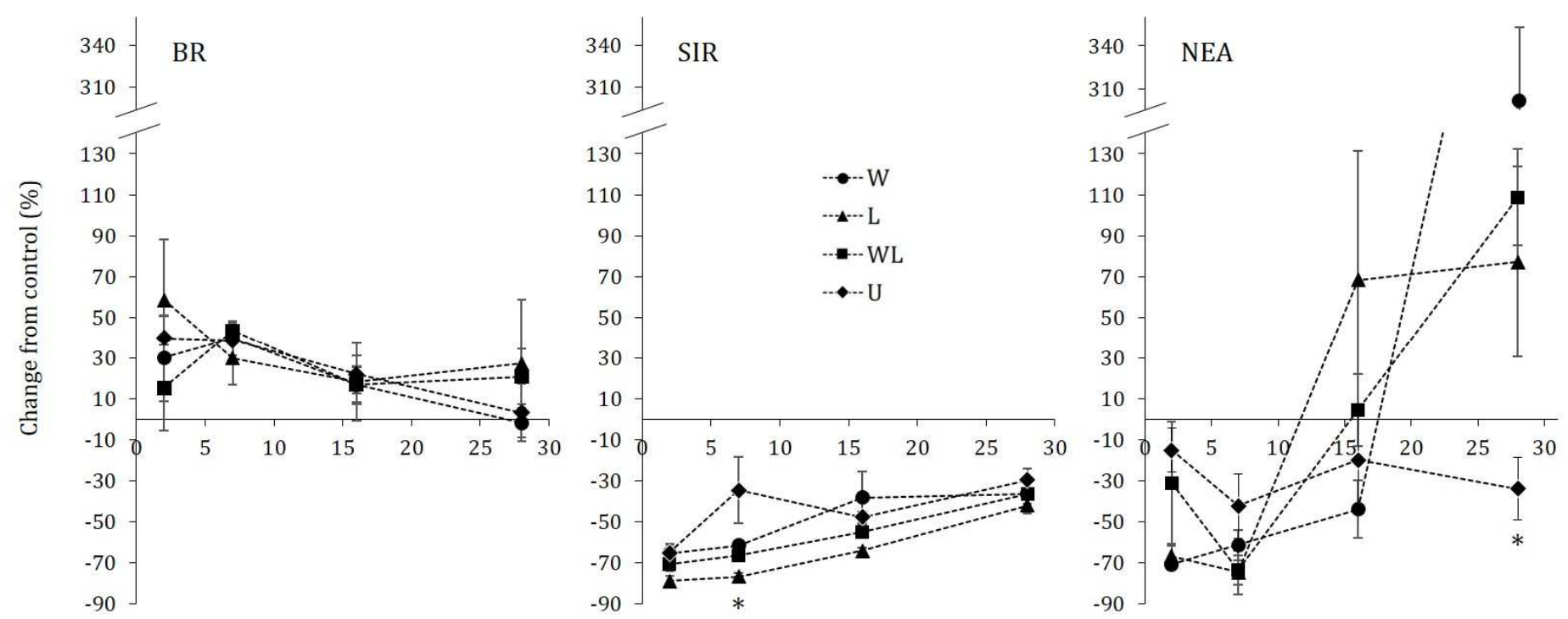

Sampling dates after stress

Fig. 2. Percentages of change in microbial activities (BR - basal respiration, SIR - substrate-induced respiration, NEA nitrification enzyme activity) relative to controls along all sampling dates after the end of the heat stress (T2, T7, T16, T28). Symbols represent planting legacy (W - wheat, L - white lupin, WL - wheat + lupin, U - unplanted). Vertical bars indicate standard errors $(\mathrm{n}=4)$. Asterisks indicate significant differences between planting legacies within a sampling date (one-way ANOVA, followed by a Tukey post hoc test $(p<0.05)$ ). 

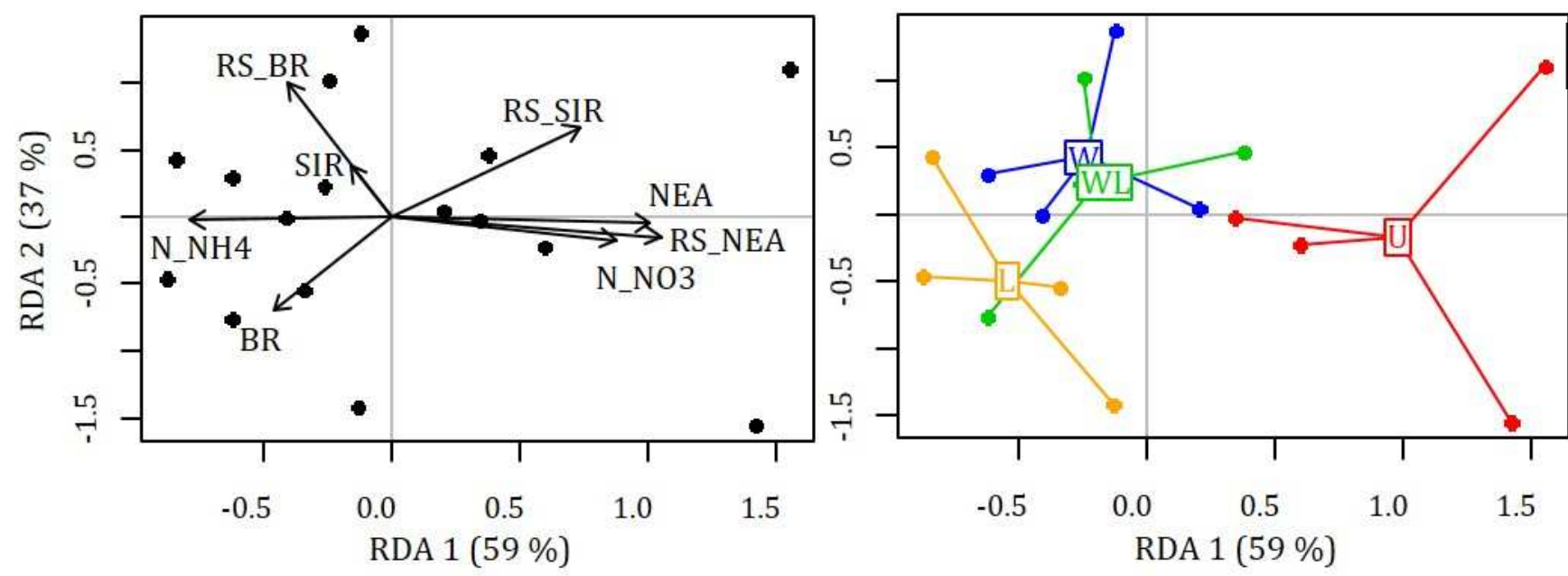

(a)
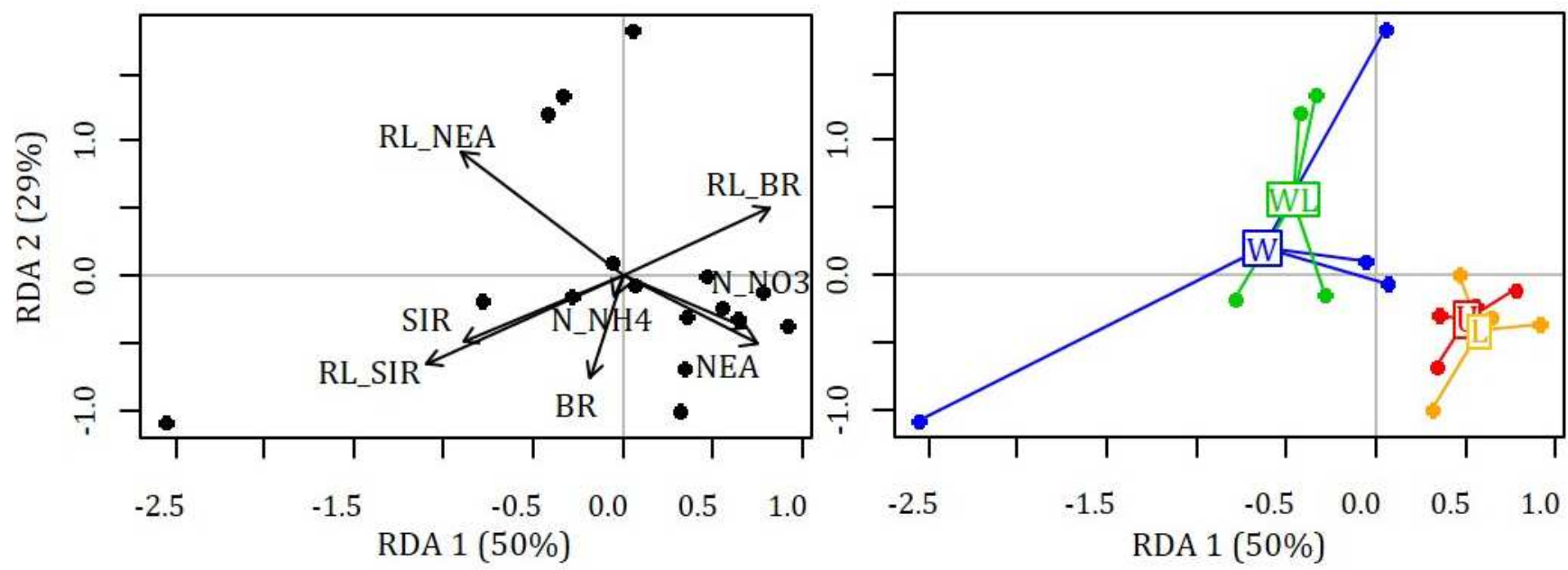

(b)

Fig. 3. Redundancy analysis (RDA) based on resistance (RS) (a) or resilience (RL) (b) indices of basal respiration (BR), substrate-induced respiration (SIR) and nitrification enzyme activity (NEA), constrained by BR, SIR, NEA, as well as soil mineral $\mathrm{N}$ content as nitrate $\left(\mathrm{N}-\mathrm{NO}_{3}{ }^{-}\right)$and ammonium $\left(\mathrm{N}^{-\mathrm{NH}_{4}}{ }^{+}\right)$. Resistance indices were calculated for T2, whereas resilience indices were calculated for T16 ( 2 and 16 days after the end of the heat stress). Groups of planting legacies are represented by $\mathrm{W}$ (wheat) in blue, L (lupin) in orange, WL (wheat + lupin) in green and U (unplanted) in red. The RDA was performed on center-reduced matrix. 


\begin{tabular}{|c|c|c|c|c|c|c|c|c|c|c|c|c|}
\hline \multirow[b]{2}{*}{ Variable } & \multirow[b]{2}{*}{ Factor } & \multicolumn{3}{|c|}{$\mathrm{T} 2$} & \multicolumn{2}{|c|}{$\mathrm{T} 7$} & \multicolumn{4}{|c|}{$\mathrm{T} 16$} & \multicolumn{2}{|c|}{$\mathrm{T} 28$} \\
\hline & & & & & & & & & & & & \\
\hline \multirow{8}{*}{$\mathrm{BR}$} & \multirow{4}{*}{$\begin{array}{l}\text { Planting legacy } \\
\text { Heat stress } \\
\text { Planting x Stress }\end{array}$} & \multicolumn{2}{|c|}{$<0.001^{* * *}$} & & \multicolumn{2}{|c|}{$<0.001^{* * *}$} & & \multicolumn{2}{|c|}{$<0.05^{*}$} & & \multicolumn{2}{|c|}{ ns } \\
\hline & & \multicolumn{2}{|c|}{$<0.01^{* *}$} & & \multicolumn{2}{|c|}{$<0.001^{* * *}$} & & \multicolumn{2}{|c|}{$<0.05^{*}$} & & \multicolumn{2}{|c|}{ ns } \\
\hline & & \multicolumn{2}{|c|}{ ns } & & \multicolumn{2}{|c|}{ ns } & & \multicolumn{2}{|c|}{ ns } & & \multicolumn{2}{|c|}{ ns } \\
\hline & & ControlB $^{\mathrm{B}}$ & Stress $^{A}$ & & ControlB $^{B}$ & Stress $^{A}$ & & Controlв & Stress $^{\mathrm{A}}$ & & Control & Stress \\
\hline & $\mathrm{W}$ & $32.82 \mathrm{ab}$ & $41.39 \mathrm{ab}$ & $\mathrm{BC}$ & $21.52 b$ & 29.79 bc & В & $20.18 \mathrm{a}$ & $22.73 \mathrm{a}$ & $\mathrm{AB}$ & $20.07 \mathrm{a}$ & $19.31 \mathrm{a}$ \\
\hline & $\mathrm{L}$ & $41.61 \mathrm{a}$ & $63.79 \mathrm{a}$ & A & $37.91 \mathrm{a}$ & $48.14 \mathrm{a}$ & A & $21.79 \mathrm{a}$ & $24.76 \mathrm{a}$ & A & $20.19 \mathrm{a}$ & $23.88 \mathrm{a}$ \\
\hline & WL & 39.32 a & $43.41 \mathrm{ab}$ & $\mathrm{AB}$ & $21.56 \mathrm{~b}$ & $38.46 \mathrm{ab}$ & в & $20.99 a$ & $24.37 \mathrm{a}$ & A & $15.78 \mathrm{a}$ & $18.37 \mathrm{a}$ \\
\hline & $\mathrm{U}$ & $23.73 \mathrm{~b}$ & $33.23 \mathrm{~b}$ & $\mathrm{C}$ & $18.63 \mathrm{~b}$ & $25.30 \mathrm{c}$ & в & $16.17 \mathrm{a}$ & $19.21 \mathrm{a}$ & B & $16.50 \mathrm{a}$ & $16.12 \mathrm{a}$ \\
\hline \multirow{8}{*}{ SIR } & \multirow{3}{*}{$\begin{array}{l}\text { Planting legacy } \\
\text { Heat stress } \\
\text { Planting x Stress }\end{array}$} & \multirow{3}{*}{\multicolumn{2}{|c|}{$\begin{array}{l}<0.001^{* * *} \\
<0.001^{* * *} \\
<\mathbf{0 . 0 0 1}^{* * *}\end{array}$}} & & \multirow{3}{*}{\multicolumn{2}{|c|}{$\begin{array}{l}<0.001^{* * *} \\
<0.001^{* * *} \\
<\mathbf{0 . 0 0 1} * * *\end{array}$}} & & \multicolumn{2}{|c|}{$<0.001^{* * *}$} & & \multicolumn{2}{|c|}{$<0.001^{* * *}$} \\
\hline & & & & & & & & \multicolumn{2}{|c|}{$<0.001^{* * *}$} & & \multicolumn{2}{|c|}{$<0.001^{* * *}$} \\
\hline & & & & & & & & \multicolumn{2}{|c|}{$<0.001^{* * *}$} & & \multicolumn{2}{|c|}{$<0.01^{* *}$} \\
\hline & & Control & Stress & & Control & Stress & & Control & Stress & & Control & Stress \\
\hline & $\mathrm{W}$ & $5.77 \mathrm{c}$ & $2.01 \mathrm{~d}$ & & $4.33 \mathrm{c}$ & $1.65 \mathrm{e}$ & & $4.21 \mathrm{bc}$ & $2.64 \mathrm{de}$ & & $4.94 \mathrm{bc}$ & $3.15 \mathrm{de}$ \\
\hline & $\mathrm{L}$ & $12.42 \mathrm{a}$ & $2.59 \mathrm{~d}$ & & $9.11 \mathrm{a}$ & $2.10 \mathrm{e}$ & & $7.69 \mathrm{a}$ & $2.75 \mathrm{de}$ & & $6.92 \mathrm{a}$ & $4.00 \mathrm{~cd}$ \\
\hline & WL & $9.24 \mathrm{~b}$ & $2.78 \mathrm{~d}$ & & $6.56 \mathrm{~b}$ & $2.20 \mathrm{de}$ & & $5.38 \mathrm{~b}$ & $2.41 \mathrm{de}$ & & $5.38 \mathrm{~b}$ & $3.43 \mathrm{de}$ \\
\hline & $\mathrm{U}$ & $4.98 \mathrm{c}$ & $1.72 \mathrm{~d}$ & & $3.50 \mathrm{~cd}$ & $1.71 \mathrm{e}$ & & $3.47 \mathrm{~cd}$ & $1.81 \mathrm{e}$ & & $3.82 \mathrm{~d}$ & $2.67 \mathrm{e}$ \\
\hline & Planting legacy & $<0.0$ & $1 * * *$ & & $<0.0$ & $01^{* * *}$ & & $<0.0$ & $1^{* * *}$ & & $<0.0$ & $1^{* * *}$ \\
\hline & Heat stress & $<0.0$ & $1 * * *$ & & $<0.0$ & $01^{* * *}$ & & & & & $<0$. & $5^{*}$ \\
\hline & Planting x Stress & $\mathrm{n}$ & & & $\mathrm{n}$ & $S$ & & & & & $<0.0$ & $1^{* * *}$ \\
\hline & & ControlA & Stress $^{\mathrm{B}}$ & & Control $^{\mathrm{A}}$ & Stress $^{\mathrm{B}}$ & & Control & Stress & & Control & Stress \\
\hline NEA & $\mathrm{W}$ & $0.54 \mathrm{~b}$ & $0.16 \mathrm{~b}$ & в & $0.40 \mathrm{~b}$ & $0.15 \mathrm{~b}$ & B & $0.59 \mathrm{~b}$ & $0.30 \mathrm{~b}$ & в & $0.65 \mathrm{c}$ & $2.69 \mathrm{bc}$ \\
\hline & $\mathrm{L}$ & $0.54 \mathrm{~b}$ & $0.17 \mathrm{~b}$ & в & $0.57 \mathrm{ab}$ & $0.12 \mathrm{~b}$ & в & $0.74 \mathrm{~b}$ & $1.12 \mathrm{ab}$ & в & $2.83 \mathrm{bc}$ & $4.66 \mathrm{~b}$ \\
\hline & WL & $0.42 \mathrm{~b}$ & $0.28 \mathrm{~b}$ & в & $0.40 \mathrm{~b}$ & $0.11 \mathrm{~b}$ & в & $0.43 \mathrm{~b}$ & $0.45 \mathrm{ab}$ & В & $1.28 \mathrm{c}$ & $2.63 \mathrm{bc}$ \\
\hline & $\mathrm{U}$ & $1.44 \mathrm{a}$ & $1.21 \mathrm{a}$ & $\mathrm{A}$ & $0.91 \mathrm{a}$ & $0.49 \mathrm{a}$ & A & $1.99 \mathrm{a}$ & $1.36 \mathrm{a}$ & $\mathrm{A}$ & $8.63 \mathrm{a}$ & $5.38 \mathrm{~b}$ \\
\hline
\end{tabular}

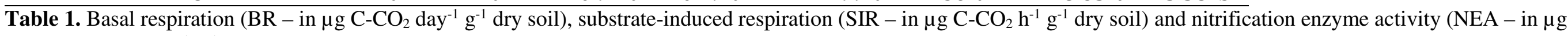
$\mathrm{N}-\mathrm{NO}_{2}{ }^{-}+\mathrm{N}-\mathrm{NO}_{3}{ }^{-} \mathrm{h}^{-1} \mathrm{~g}^{-1}$ dry soil) of each planting legacy (W - wheat, $\mathrm{L}-$ lupin, $\mathrm{WL}$ - wheat+lupin, $\mathrm{U}-$ unplanted), within control and stress conditions, for each sampling date after the end of the heat stress (T2, T7, T16, T28). Values are the means of four replicates $(n=4)$. Thresholds of probability of the two-way ANOVA (Planting x Stress) are indicated at the top of each variable-related data set. When significant interaction between factors (Planting $\mathrm{x}$ Stress) is present, different bold letters represent significant differences between 8 means (i.e. control and heat stress conditions combined; Tukey post hoc test $(p<0.05)$ ). Different lowercase letters represent significant differences within a single column, whereas different uppercase letters represent either significant differences between stress conditions (Control $v s$ Stress), or between planting legacies with control and stress conditions combined (Tukey post hoc test $(p<0.05)$ ). 


\begin{tabular}{|c|c|c|c|c|c|}
\hline Variable & \multirow{2}{*}{$\frac{\text { Plant legacy }}{\mathrm{W}}$} & \multirow{2}{*}{$\frac{\text { (Resistance) }}{0.52}$} & \multicolumn{3}{|c|}{ (Resilience) } \\
\hline & & & -0.00 & 0.27 & 0.48 \\
\hline \multirow[t]{2}{*}{$\mathrm{BR}$} & $\mathrm{L}$ & 0.34 & 0.31 & 0.55 & 0.27 \\
\hline & WL & 0.60 & -0.22 & 0.20 & 0.26 \\
\hline \multicolumn{2}{|c|}{$p$-value (one-way ANOVA) } & 0.61 & 0.31 & 0.61 & 0.86 \\
\hline \multirow{3}{*}{ SIR } & $\mathrm{W}$ & $0.21 \mathrm{a}$ & 0.16 & 0.47 & $0.35 \mathrm{~b}$ \\
\hline & $\mathrm{L}$ & 0.11 b & 0.16 & 0.32 & $0.54 \mathrm{a}$ \\
\hline & WL & $0.17 \mathrm{ab}$ & 0.19 & 0.37 & $0.53 \mathrm{a}$ \\
\hline \multicolumn{2}{|c|}{$p$-value (one-way ANOVA) } & $0.05^{*}$ & 0.87 & 0.63 & $0.04^{*}$ \\
\hline \multirow{3}{*}{ NEA } & $\mathrm{W}$ & 0.17 & 0.21 & $0.24 \mathrm{a}$ & -0.63 \\
\hline & $\mathrm{L}$ & 0.20 & -0.03 & $-0.58 b$ & -0.48 \\
\hline & WL & 0.29 & -0.10 & 0.46 a & -0.68 \\
\hline \multicolumn{2}{|c|}{$p$-value (one-way ANOVA) } & 0.34 & 0.16 & $0.008^{* *}$ & 0.56 \\
\hline
\end{tabular}

Table 2. Indices of resistance and resilience based on basal respiration (BR), substrate-induced respiration (SIR) and nitrification enzyme activity (NEA) for each specific plant legacy (W - wheat, L - lupin, WL - wheat+lupin). Resistance indices were calculated on T2 date ( 2 days after the end of the heat stress), whereas resilience indices were calculated on T7, T16 and T28 dates of measure (7,16 and 28 days after the end of the heat stress). Values are the means of four replicates $(n=4)$. Probabilities of the one-way ANOVA are indicated at the bottom of each variable-related data set. Different letters represent significant differences within a column (Tukey post hoc test $(p<0.05)$ ). 